\title{
Efficiency and Productivity Change of Selected Online Banks in Bangladesh: A Non-parametric Malmquist Approach
}

\section{Md. Azizul Baten ${ }^{1 *}$, Kasim $\mathbf{M M}^{1}$ and Rahman $\mathbf{M}^{2}$}

${ }^{1}$ Department of Decision Science, School of Quantitative Sciences, Universiti Utara Malaysia, Malaysia

${ }^{2}$ Department of Statistics, Shahjalal University of Science and Technology, Bangladesh

\begin{abstract}
This study evaluated the technical efficiency change and productivity change of national commercial banks (NCBs) and private banks (PBs) by employing cost data envelopment analysis (DEA), profit DEA and Malmquist based DEA. The cost inefficiency and profit efficiency are observed slightly higher for PBs than NCBs. The average technical and allocative efficiency are found $75.4 \%$ and $35.9 \%$ respectively by cost DEA; while $74.0 \%$ and $31.8 \%$ for profit DEA. By profit DEA, on an average bank-wise and year-wise productivity change, efficiency change and technical efficiency change are found higher than cost DEA. The average cost and average profit efficiency is observed $28.7 \%$ and $24.2 \%$ respectively. Bank-wise average productivity change and technical efficiency change are decreased at $4.2 \%$ and $5.1 \%$ respectively whereas the efficiency change is increased at $0.9 \%$ in profit DEA. The bank-wise productivity change and technical efficiency change and efficiency change are recorded decreased at $8.4 \%, 6.2 \%$ and $1.8 \%$ respectively in cost DEA. It is expected that there exist a huge gap among NCBs in terms of cost efficiency, so NCBs should decrease cost after performing adequate inquiries so that these cost could be recovered.
\end{abstract}

Keywords: Efficiency; Cost data envelopment analysis; Profit data envelopment analysis; Malmquist DEA; National commercial banks; Private banks; Bangladesh

\section{Introduction}

Measurement of efficiency and productivity in the banking sector has always been the areas of interest for economic research. To measure performance of banking sector, two kinds of measurements are widely used namely financial ratios measures and efficiency measures. In the case of financial ratios, these are computed to highlight a particular aspect of a bank activity. Since banking industry uses multiple inputs to produce multiple outputs, a precise inference may not always be possible. In order to overcome this limitation alternative techniques are employed to compute total factor productivity of a banking unit which covers all aspects of banking operations in a single measure. Efficiency in the banking system leads to more innovations, improved profitability as well as greater safety and soundness when improvement in productivity is channelled towards strengthening capital buffers that absorb risk [1]. Therefore, the banking industry needed to improve its efficiency level so that it could further contribute to the country's economic expansion.

One of the most well-known and early approach to efficiency is the data envelopment analysis (DEA). While DEA examines total efficiency, Stochastic Frontier Analysis examines only the technical change aspects. This approach helps to overcome a primary shortcoming of the DEA of not accommodating measurement errors, which could have an influence on the shape and position of the estimated frontier according to Seiford and Thrall, Bauer, and Greene [2-4]. The findings of Sohrab and Suzuki [5] indicate that cost efficiency of sample banks have increased by $15.2 \overline{8 \%}$ using DEA based frontier technique. However, the recent study of Hoque and Rayhan [6] found that CRS-DEA consists of 3 efficient banks out of 24 banks whereas VRS-DEA consists of 12 efficient banks in Bangladesh. Due to these contradicting results which are interesting in re-examining this issue of efficiency and productivity change in the Bangladeshi banking institutions for a more recent period. Again, most of the researches focus on traditional ratio analysis and simple banking indicators to investigate the performance of commercial banks. Chowdhury and Ahmed [7] measure the performance of 5 private commercial banks from the period 2002-2006. The main limitation of Chowdhury and
Ahmed [7] study is that the sample size is too small and it does not reflect the true picture of the entire banking sector. The research of Hoque et al. [8] incorporates overall category wise data of different types of banks for assessing bank performance. Their study employs both cross sectional analysis and time series analysis with a sample period of 1988-1998 and uses different traditional ratios. Thus, this review suggests that the Bangladeshi banks should be studied using cost DEA, profit DEA methods and Malmquist Indices. The present study uses individual bank data rather than focusing on overall category wise data to generate clearer picture of bank performance after financial reform and to identify the ownership effect on bank performance. Further, it is important to also investigate the determinants or the sources of bank efficiency performance of Bangladesh.

There are several reasons to choose to apply profit DEA and cost DEA models here. First, the DEA model is able to incorporate multiple inputs and outputs easily. Second a parametric functional form does not have to be specified for the production function. Third DEA has the potential to provide information to the supervisors in improving the productive efficiency of the organization. Finally, DEA presents a generalization approach because other assumptions than constant return to scale can be accommodated within a convex piecewise linear best practice frontier. Again, according to Bhattacharyya et al. [9] there is every possibility that restrictive atmosphere and market imperfections distort the prices of inputs and outputs to a great extent in developing countries that makes the application of parametric techniques for computing cost and profit efficiency more complicated. Furthermore, parametric techniques require prior estimation of the functional form and availability of large data for determining profit and cost efficiency,

*Corresponding author: Md. Azizul Baten, Visiting Professor Madya, Department of Decision Science, School of Quantitative Sciences, Universiti Utara Malaysia, Malaysia, Tel: +69286425; E-mail: baten_math@yahoo.com

Received August 01, 2015; Accepted August 31, 2015; Published September 10,2015

Citation: Baten A, Kasim MM, Rahman M (2015) Efficiency and Productivity Change of Selected Online Banks in Bangladesh: A Non-parametric Malmquist Approach. J Internet Bank Commer 20: 121. doi:10.4172/2165-7866.1000121

Copyright: ( 2015 Baten A, et al. This is an open-access article distributed unde the terms of the Creative Commons Attribution License, which permits unrestricted use, distribution, and reproduction in any medium, provided the original author and source are credited. 
which is not always possible in the context of a developing country like Bangladesh. This paper aims to investigate efficiency of Bangladesh commercial banks and private banks from 2001-2010 by employing a non-parametric approach, namely, the cost DEA and profit DEA. Secondly this paper investigates the productivity change during this period by employing Malmquist Productivity Index.

\section{Overview of the banking sector in Bangladesh}

After the independence in 1971, Bangladesh adopted state directed credit policy with a view to rehabilitating the economy. Until 1982, private commercial banks were not allowed to operate and the banking sector was predominantly dictated by government owned commercial and specialized banks (SPBs). It was started with privatization and denationalization in 1982-1983 followed by the introduction of Financial Sector Reform Program (FSRP) during 1989-1990 in order to deregulate the banking sector as per the recommendations given by the National Commission on Money, Banking, and Credit and World Bank.

Bangladesh Bank is at the top of the banking system and is accountable for assuring prudential administration and central banking activities for all types of banks operating within the banking industry. According to the Bangladesh Bank Annual Report (20082009), the banking system of Bangladesh consists of 4 nationalized commercial banks (NCBs), 5 government owned SPBs, 30 domestic private commercial banks (PCBs) including 7 Islamic banks and 2 denationalized banks, and 9 foreign commercial banks (FCBs). The share of government owned banks in total banking assets, deposits, and credits are $37.82 \%, 35.00 \%$, and $32.04 \%$ respectively. On the other hand, PCBs hold $54.16 \%$ of the total banking assets, out of which non-Islamic banks, Islamic banks, and denationalized banks capture $36.16 \%, 14.00 \%$ and $4.00 \%$ respectively. All nine FCBs hold $8.36 \%$, $7.09 \%$ and $8.02 \%$ of the entire banking deposits, credits, and assets. The PCBs retain the majority of the total deposits and loans, which are $56.64 \%$ and $60.87 \%$.

\section{Materials and Methods}

\section{Data and variables}

The data are used from the period of 2001 to 2010 for 17 banks of Bangladesh and two categories of bank (i) National Commercial Banks (NCBs), (ii) Private Banks (PBs) are considered. Most of the data are collected from the annual reports of the specific banks of Bangladesh and the data are collected from annual accounts of Scheduled Commercial Banks published by Bangladesh Bank, the central bank of Bangladesh. All variables except for the input price and output are measured in millions of Bangladeshi taka.

\section{Output variables}

Cost: It is measured as total cost, defined by all expenses of bank such as salary and allowances, rent, taxes, insurance, lighting, stationary, managing director's remuneration, depreciation cost of bank.

Profit: It is measured as total profit after tax.

Advance: It is measured as total loan and advance minus loan.

Other earning assets: It is measured by total other assets.

off-balance sheet items: It is measured by total off-balance sheet items including contingent liabilities.

\section{Input variables}

Price of fixed assets: It is measured as total repairing cost of fixed assets.

Price of labour: It is measured as total salary and allowances.

Price of borrowed fund: It is measured by total borrowed including inside and outside of Bangladesh.

\section{Input quantities}

Fixed assets: It is measured by number of fixed assets such as building, furniture, fixture, office appliance, and motor vehicles etc., multiplied by number of branch. bank.

Number of labour: This is measured as full-time equivalents of

\section{Methods}

This study employs both profit DEA and cost DEA models to estimate the technical efficiency scores and then malumquist productivity measure to identify efficiency gain/loss of the commercial banks and private banks in Bangladesh. The main advantage of DEA as compared to the econometric approach is that it does not require a priori functional specification of the unknown technology [10,11].

Profit data envelopment analysis: Let us consider $n$ banks, each one producing different output $(\mathrm{y})$ and using different inputs $(\mathrm{x})$. The profit efficiency of the bank assuming constant return scale (CRS) is measured as follows:

$\operatorname{Max}_{u, v}\left(u^{\prime} y_{i} / v^{\prime} x_{i}\right)$

Subject to

$u^{\prime} y_{j}-v^{\prime} x_{j} \leq 0, \quad j=1,2, \ldots, N$

$u, v \geq 0$.

Where $x$ is a vector of bank inputs, $y$ is a vector of bank output given the inputs, $u$ is the weighted relative vector associated to output, $v$ is the weighted relative vector associated to input.

Cost data envelopment analysis: The cost efficiency of the bank assuming variable return to scale (VRS) is measured as follows

$$
\begin{aligned}
& \operatorname{Min}_{\theta, \lambda} \theta, \\
& \text { St } \quad-y_{i}+Y \lambda \geq 0, \\
& \theta x_{i}-X \lambda \geq 0, \\
& \text { NI' } \lambda=1 \\
& \lambda \geq 0,
\end{aligned}
$$

where $\mathrm{X}$ is $m \times n$ input matrix, $\mathrm{Y}$ is $s \times n$ output matrix, NI is an $N \times 1$ vector of ones, $\lambda$ is an $n \times 1$ vector of constant and $\theta$ is a scalar. The value of $\theta$ obtained is the efficiency score for the $\mathrm{i}$-th bank. It satisfies $\theta \leq 1$, with a value of 1 indicating a point on the frontier and hence a technical efficiency bank. The convexity constraint NI' $\lambda=1$ ensures that an inefficient firm is only benchmarked against firms of similar size.

Scale efficiency refers to the bank's ability to work at its optimal scale. It can be defined as:

$$
T E_{C R S}=T E_{V R S} \times S E
$$

Where $\mathrm{TE}_{\mathrm{CRS}}$ is the technical efficiency, $\mathrm{TE}_{\mathrm{VRS}}$ is the pure technical efficiency, and SE is the Scale efficiency. The technical efficiency 
obtained by CRS DEA model can be decomposed in two parts, one due to scale efficiency, and one due to pure technical efficiency. Pure technical efficiency refers to the bank's ability to avoid waste by producing as much output as input usage allows, or by using as little input as output production allows.

Malmquist total factor productivity index: In order to measure productivity change decomposed as the technical change and efficiency change Malmquist Index is calculated using DEA. Fare et al. [12] specify an output-based Malmquist productivity change index as:

$$
M_{0}^{t+1}\left(x^{t+1}, y^{t+1}, x^{t}, y^{t}\right)=\left[\frac{D_{0}^{t}\left(x^{t+1}, y^{t+1}\right)}{D_{0}^{t}\left(x^{t}, y^{t}\right)} \frac{D_{0}^{t+1}\left(x^{t+1}, y^{t+1}\right)}{D_{0}^{t+1}\left(x^{t}, y^{t}\right)}\right]^{1 / 2}
$$

This productivity index is the geometric mean of a pair of ratios of output distance function. The first ratio compares the performance of the data from period $t$ to $t+1$ relative to production possibilities existing in period $t$, and the second compares the performance of the same data relative to production possibilities in period $\mathrm{t}+1$.

Fare et al. [13] decomposed this index into sub indexes measuring changes in efficiency and changes in technology:

$$
M_{0}^{t+1}\left(x^{t+1}, y^{t+1}, x^{t}, y^{t}\right)=\frac{D_{0}^{t+1}\left(x^{t+1}, y^{t+1}\right)}{D_{0}^{t}\left(x^{t}, y^{t}\right)}\left[\frac{D_{0}^{t}\left(x^{t+1}, y^{t+1}\right)}{D_{0}^{t+1}\left(x^{t+1}, y^{t+1}\right)} \frac{D_{0}^{t+1}\left(x^{t}, y^{t}\right)}{D_{0}^{t+1}\left(x^{t}, y^{t}\right)}\right]^{1 / 2}
$$

The first term of the equation is the change in technical efficiency; and the second term is the change in technology.

Fare et al. [14] further decomposed the Malmquist index by rewriting equation (5) as:

$$
\begin{aligned}
& M_{0}^{t+1}\left(x^{t+1}, y^{t+1}, x^{t}, y^{t}\right)=\left[\frac{\Delta_{0}^{t+1}\left(x^{t+1}, y^{t+1}\right) / D_{0}^{t+1}\left(x^{t+1}, y^{t+1}\right)}{\Delta_{0}^{t}\left(x^{t}, y^{t}\right) / D_{0}^{t}\left(x^{t}, y^{t}\right)}\right] *\left[\frac{D_{0}^{t}\left(x^{t}, y^{t}\right)}{D_{0}^{t+1}\left(x^{t+1}, y^{t+1}\right)} * \frac{D_{0}^{t}\left(x^{t}, y^{t}\right)}{D_{0}^{t+1}\left(x^{t}, y^{t}\right)}\right]^{1 / 2} \\
& *\left[\frac{\Delta_{0}^{t+1}\left(x^{t+1}, y^{t+1}\right) / D_{0}^{t}\left(x^{t+1}, y^{t+1}\right)}{\Delta_{0}^{t+1}\left(x^{t+1}, y^{t+1}\right) / D_{0}^{t+1}\left(x^{t+1}, y^{t+1}\right)} * \frac{\Delta_{0}^{t}\left(x^{t}, y^{t}\right) / D_{0}^{t}\left(x^{t}, y^{t}\right)}{\Delta_{0}^{t+1}\left(x^{t}, y^{t}\right) / D_{0}^{t+1}\left(x^{t}, y^{t}\right)}\right]^{1 / 2}
\end{aligned}
$$

Fare et al. refers the first term as a measure of change in scale efficiency and the second term as a measure of pure efficiency change. The last term is unchanged and it gives a measure of change in technology.

\section{Results and Discussion}

\section{Bank-wise estimation of cost and profit efficiency by DEA}

The cost and profit efficiency estimates have been measured using DEA applied to panel data. From cost DEA and profit DEA models, technical efficiency (TE), allocative efficiency (AE), cost efficiency (CE) and profit efficiency (PE) have been estimated. The productivity change has been estimated through Malmquist DEA based Index. This also devotes to examine the overall performance of banks in Bangladesh.

The evaluation of technical efficiency, allocative efficiency, cost efficiency and profit efficiency for the selected sample banks is presented in Table 1. The average technical and allocative efficiency are found $75.4 \%$ and $35.9 \%$ respectively through cost DEA model. The technical efficiency is found greater than allocotive efficiency for the selected banks. The results of technical efficiency and allocative efficiency are combined to provide a measure of total cost efficiency through cost DEA model. The lowest cost efficiency is $6.6 \%$ for $A B$ Bank and highest cost efficiency is $100 \%$ for both Mutual Trust Bank and One Bank.

The average technical and allocative efficiency are found $74.0 \%$ and $31.8 \%$ respectively through profit DEA model. The technical efficiency is observed higher than the allocative efficiency for all sample banks. The results of technical efficiency and allocative efficiency are combined to provide a measure of total profit efficiency using profit DEA. The lowest profit efficiency is $5.3 \%$ for $A B$ Bank and the highest profit efficiency $100 \%$ for One Bank. The average cost and profit efficiency is recorded $28.7 \%$ and $24.2 \%$ respectively in case of cost DEA and profit DEA.

\section{Year-wise estimation of productivity and efficiency change by cost DEA}

\begin{tabular}{|c|c|c|c|c|c|c|c|}
\hline \multirow[t]{2}{*}{ Name of the Banks } & \multirow[t]{2}{*}{ Serial No. } & \multicolumn{3}{|c|}{ Cost Efficiency } & \multicolumn{3}{|c|}{ Profit Efficiency } \\
\hline & & TE & $\mathrm{AE}$ & CE & TE & $\mathrm{AE}$ & PE \\
\hline AB Bank & 1 & 0.276 & 0.240 & 0.066 & 0.268 & 0.201 & 0.053 \\
\hline Bank Asia & 2 & 0.869 & 0.809 & 0.703 & 0.618 & 0.607 & 0.375 \\
\hline BRAC Bank & 3 & 0.653 & 0.584 & 0.381 & 0.692 & 0.293 & 0.202 \\
\hline Dhaka Bank & 4 & 0.306 & 0.199 & 0.061 & 0.323 & 0.306 & 0.099 \\
\hline Dutch Bangla Bank & 5 & 0.429 & 0.408 & 0.175 & 0.450 & 0.473 & 0.213 \\
\hline Eastern Bank & 6 & 0.458 & 0.236 & 0.108 & 0.458 & 0.090 & 0.041 \\
\hline Mercantile Bank & 7 & 0.788 & 0.471 & 0.371 & 0.622 & 0.450 & 0.280 \\
\hline Mutual Trust Bank & 8 & 1.000 & 1.000 & 1.000 & 0.882 & 0.891 & 0.786 \\
\hline National Bank & 9 & 0.596 & 0.111 & 0.066 & 0.596 & 0.103 & 0.061 \\
\hline One Bank & 10 & 1.000 & 1.000 & 1.000 & 1.000 & 1.000 & 1.000 \\
\hline Prime Bank & 11 & 0.832 & 0.196 & 0.163 & 0.830 & 0.166 & 0.138 \\
\hline Pubali Bank & 12 & 0.750 & 0.170 & 0.128 & 0.847 & 0.088 & 0.074 \\
\hline South East Bank & 13 & 1.000 & 0.262 & 0.262 & 1.000 & 0.323 & 0.323 \\
\hline Sonali Bank & 14 & 0.867 & 0.104 & 0.090 & 1.000 & 0.122 & 0.122 \\
\hline United Commercial Bank & 15 & 1.000 & 0.130 & 0.130 & 1.000 & 0.117 & 0.177 \\
\hline Uttara Bank & 16 & 1.000 & 0.152 & 0.152 & 1.000 & 0.098 & 0.098 \\
\hline \multirow[t]{2}{*}{ Janata Bank } & 17 & 1.000 & 0.026 & 0.026 & 1.000 & 0.077 & 0.077 \\
\hline & Mean & 0.754 & 0.359 & 0.287 & 0.740 & 0.318 & 0.242 \\
\hline
\end{tabular}

The productivity changes are presented in Table 2 . The total productivity of selected bank is increased from 2001 to 2002, at the rate equal to $51.8 \%(\mathrm{TFPC}=1.518)$. It is obvious that the Technical

TE: Technical Efficiency; AE: Allocative Efficiency; CE: Cost Efficiency; PE: Profit Efficiency.

Table 1: Bank-wise cost and profit efficiency by data envelopment analysis (DEA). 


\begin{tabular}{|l|c|c|c|c|}
\hline Year & EC & TEC & PEC & SEC \\
\hline $2001-2002$ & 0.921 & 1.647 & 1.000 & 0.921 \\
\hline $2002-2003$ & 1.030 & 0.899 & 1.000 & 1.030 \\
\hline $2003-2004$ & 0.969 & 0.668 & 1.000 & 0.969 \\
\hline $2004-2005$ & 0.854 & 1.135 & 1.000 & 0.926 \\
\hline $2005-2006$ & 1.096 & 1.089 & 1.000 & 1.096 \\
\hline $2006-2007$ & 1.039 & 0.811 & 1.000 & 1.039 \\
\hline $2007-2008$ & 0.962 & 0.887 & 0.969 & 0.962 \\
\hline $2008-2009$ & 1.156 & 0.877 & 1.000 & 1.000 \\
\hline $2009-2010$ & 0.850 & 0.695 & 0.843 \\
\hline Mean & $\mathbf{0 . 9 8 2}$ & $\mathbf{0 . 9 3 3}$ & 1.000 & \\
\hline
\end{tabular}

Table 2: Year-wise productivity and efficiency change for cost DEA.

\begin{tabular}{|c|c|c|c|c|c|c|}
\hline Name of the Banks & Number of Bank & EC & TEC & PEC & SEC & TFPC \\
\hline AB Bank & 1 & 1.064 & 1.009 & 1.000 & 1.064 & 1.073 \\
\hline Bank Asia & 2 & 0.979 & 1.055 & 1.000 & 0.979 & 1.033 \\
\hline BRAC Bank & 3 & 1.000 & 1.067 & 1.000 & 1.000 & 1.067 \\
\hline Dhaka Bank & 4 & 1.000 & 1.019 & 1.000 & 1.000 & 1.019 \\
\hline Dutch Bangla Bank & 5 & 0.998 & 0.976 & 1.000 & 0.998 & 0.974 \\
\hline Eastern Bank & 6 & 1.005 & 0.931 & 1.000 & 1.005 & 0.935 \\
\hline Mercantile Bank & 7 & 1.040 & 0.915 & 1.000 & 1.040 & 0.952 \\
\hline Mutual Trust Bank & 8 & 0.941 & 0.820 & 1.000 & 0.941 & 0.772 \\
\hline National Bank & 9 & 0.930 & 0.879 & 1.000 & 0.930 & 0.817 \\
\hline One Bank & 10 & 1.000 & 0.889 & 1.000 & 1.000 & 0.889 \\
\hline Prime Bank & 11 & 0.999 & 0.894 & 1.000 & 0.999 & 0.893 \\
\hline Pubali Bank & 12 & 0.930 & 1.024 & 1.000 & 0.930 & 0.953 \\
\hline South East Bank & 13 & 0.977 & 0.973 & 1.000 & 0.977 & 0.951 \\
\hline Sonali Bank & 14 & 0.906 & 0.839 & 1.000 & 0.906 & 0.760 \\
\hline United Commercial Bank & 15 & 1.000 & 0.883 & 1.000 & 1.000 & 0.883 \\
\hline Uttara Bank & 16 & 1.000 & 0.964 & 1.000 & 1.000 & 0.964 \\
\hline Janata Bank & 17 & 0.933 & 0.785 & 1.000 & 0.933 & 0.733 \\
\hline \multicolumn{2}{|l|}{ Mean } & 0.982 & 0.933 & 1.000 & 0.982 & 0.916 \\
\hline
\end{tabular}

EC: Efficiency Change; TEC: Technical Efficiency Change; PEC: Pure Efficiency Change; SEC: Scale Efficiency Change; TFPC: Total Factor Productivity Change.

Table 3: Bank-wise productivity and efficiency change using cost DEA.

Efficiency Change (TEC) index and Efficiency Change (EC) index are not moving towards the same direction in both cases.

Technical efficiency change is increased from 2001 to 2002, at the rate equal to $64.7 \%$ (TEC=1.647), and efficiency change is decreased by $8.5 \%$ based on the nominal values $(\mathrm{EC}=0.921)$. The total productivity change is decreased from 2002 to 2003 and 2006 to 2007, at the rate equal to $7.9 \%$ (TFPC $=0.926$ ) and $18.6 \%$ (TFPC $=0.843$ ), respectively in the selected banks. But the TEC and EC are not moving towards the same direction in both cases. Technical efficiency change is decreased and efficiency change is increased during the period 2002 to 2003 and 2006 to 2007 , at the rate (11.2\% and $23.3 \%$ ), and (3\% and $3.9 \%)$ respectively. We have obtained the cost Malmquist index, the productivity change, technical efficiency change and efficiency change and they are decreased for selected banks in the year of 2003 to 2004, 2007 to 2008 and 2009 to 2010 . On the other hand in the year of 2005 to 2006, the total productivity change, technical efficiency change and efficiency change are increased at the rate $19.3 \%$ (TFPC $=1.193), 8.9 \%$ $(\mathrm{TEC}=1.089)$ and $9.6 \%(\mathrm{EC}=1.096)$ respectively. Total productivity and efficiency change are recorded increasing in 2008 to 2009, at rate equal to $1.4 \%(\mathrm{TFPC}=1.014)$ and $15.6 \%(\mathrm{EC}=1.156)$ respectively, but technical efficiency change is decreased in the same year, at the rate of $14 \%$ (TEC $=0.877$ ). In the year of 2004 to 2005 the productivity and efficiency change are decreased, on the other hand technical efficiency is increased at the rate of $13.5 \% \quad(\mathrm{TEC}=1.135)$. The average total productivity change, technical efficiency change and efficiency change are decreased at the rate of $5 \%($ TFPC $=0.950), 3.3 \%($ TEC $=0.967)$ and $1.4 \%(\mathrm{EC}=0.986)$ respectively.

\section{Bank-wise estimation of productivity and efficiency change} by cost DEA

Cost Malmquist productivity index and efficiency change for the selected banks are represented in Table 3. Productivity index are increased of AB Bank, Bank Asia, BRAC Bank and Dhaka Bank, at the rate of $7.3 \%, 3.3 \%, 6.7 \%$ and $1.9 \%$, respectively. TFP change, TEC and EC are decreased for Dutch Bangla Bank, Mutual Trust Bank, National Bank, Prime Bank, South East Bank, Sonali Bank and Janata Bank. The average TFP index is decreased, at the rate of $7.9 \%$ (TFPC $=0.921)$ and technical efficiency change and efficiency change also decreased, at the rate of $6.2 \%$ and $1.8 \%$ respectively for selected banks.

\section{Year-wise estimation of productivity and efficiency change by profit DEA}

Profit Malmquist productivity changes and efficiency changes are presented in Table 4 . The total productivity of selected bank is increased from 2001 to 2002 and 2002 to 2003, at rate equal to $2.7 \%$ $(\mathrm{TFPC}=1.027)$ and $20.2 \% \quad(\mathrm{TFP}=1.202)$, respectively. Technical efficiency is decreased in 2001 to 2002 and increased 2002 to 2003; on the other hand efficiency change is increased during in 2001 to 2002 


\begin{tabular}{|l|l|l|l|l|}
\hline Year & EC & TEC & PEC & SEC \\
\hline $\mathbf{2 0 0 1 - 2 0 0 2}$ & 1.153 & 0.891 & 1.000 & 1.153 \\
\hline $\mathbf{2 0 0 2 - 2 0 0 3}$ & 0.832 & 1.445 & 1.000 & 0.832 \\
\hline $\mathbf{2 0 0 3 - 2 0 0 4}$ & 0.986 & 0.668 & 1.000 & 0.986 \\
\hline $\mathbf{2 0 0 4 - 2 0 0 5}$ & 0.892 & 1.150 & 1.000 & 0.892 \\
\hline $\mathbf{2 0 0 5 - 2 0 0 6}$ & 1.237 & 0.998 & 1.000 & 1.237 \\
\hline $\mathbf{2 0 0 6 - 2 0 0 7}$ & 1.033 & 0.938 & 1.000 & 1.033 \\
\hline $\mathbf{2 0 0 7 - 2 0 0 8}$ & 0.941 & 0.852 & 1.000 & 0.941 \\
\hline $\mathbf{2 0 0 8 - 2 0 0 9}$ & 1.140 & 0.905 & 0.968 \\
\hline $\mathbf{2 0 0 9 - 2 0 1 0}$ & 0.936 & 0.876 & 0.802 & 1.000 \\
\hline Mean & 1.009 & 0.949 & 1.000 & \\
\hline
\end{tabular}

Table 4: Year-wise productivity and efficiency change by profit DEA.

\begin{tabular}{|c|c|c|c|c|c|c|}
\hline Name of the Banks & Number of Bank & EC & TEC & PEC & SEC & TFPC \\
\hline AB Bank & 1 & 1.033 & 1.152 & 1.000 & 1.033 & 1.191 \\
\hline Bank Asia & 2 & 0.931 & 0.929 & 1.000 & 0.931 & 0.865 \\
\hline BRAC Bank & 3 & 1.000 & 1.075 & 1.000 & 1.000 & 1.075 \\
\hline Dhaka Bank & 4 & 1.071 & 0.950 & 1.000 & 1.071 & 1.017 \\
\hline Dutch Bangla Bank & 5 & 1.110 & 0.945 & 1.000 & 1.110 & 1.049 \\
\hline Eastern Bank & 6 & 1.000 & 0.881 & 1.000 & 1.000 & 0.881 \\
\hline Mercantile Bank & 7 & 1.008 & 0.953 & 1.000 & 1.008 & 0.960 \\
\hline Mutual Trust Bank & 8 & 0.939 & 0.844 & 1.000 & 0.939 & 0.792 \\
\hline National Bank & 9 & 1.000 & 0.869 & 1.000 & 1.000 & 0.869 \\
\hline One Bank & 10 & 1.000 & 0.904 & 1.000 & 1.000 & 0.904 \\
\hline Prime Bank & 11 & 1.000 & 0.916 & 1.000 & 1.000 & 0.916 \\
\hline Pubali Bank & 12 & 0.985 & 1.023 & 1.000 & 0.985 & 1.007 \\
\hline South East Bank & 13 & 0.988 & 0.882 & 1.000 & 0.988 & 0.871 \\
\hline Sonali Bank & 14 & 0.973 & 0.986 & 1.000 & 0.973 & 0.960 \\
\hline United Commercial Bank & 15 & 1.030 & 0.934 & 1.000 & 1.030 & 0.962 \\
\hline Uttara Bank & 16 & 1.000 & 0.991 & 1.000 & 1.000 & 0.991 \\
\hline \multirow[t]{2}{*}{ Janata Bank } & 17 & 1.100 & 0.951 & 1.000 & 1.100 & 1.046 \\
\hline & Mean & 1.009 & 0.949 & 1.000 & 1.009 & 0.958 \\
\hline
\end{tabular}

Table 5: Bank-wise productivity and efficiency change by profit DEA.

and decreased 2002 to 2003. In the year of 2003 to 2004, 2007 to 2008 and 2009 to 2010, productivity, technical efficiency and efficiency change are decreased. Total productivity is increased from 2005 to 2006 and 2008 to 2009 , at the rate of $23.4 \%(\mathrm{TFPC}=1.234)$ and $3.2 \%$ (TFPC=1.032) respectively. Technical efficiency change is decreased in both periods, at rate of $0.2 \%$ (TEC $=0.998)$ and $10.4 \%(\mathrm{TEC}=0.905)$. Efficiency change is increased also for both periods, at the rate of $23.7 \%(\mathrm{EC}=1.237)$ and $14 \%(\mathrm{EC}=1.140)$ respectively. The average total productivity and technical efficiency change are decreased, at the rate of $2.6 \%(\mathrm{TFPC}=0.974)$ and $3.1 \%$ (TEC $=0.969)$, on the other hand average efficiency change is increased at rate of $1.6 \%(\mathrm{EC}=1.016)$.

\section{Bank-wise estimation of productivity and efficiency change by profit DEA}

Profit Malmquist total productivity changes in the selected bank are presented in Table 5 . The average productivity change decreased at the rate of $3.8 \%(\mathrm{TFPC}=0.962)$ and also decreased technical efficiency change at the rate equal to $4.8 \%(\mathrm{TE}=0.952)$, but average efficiency change increased at the rate of $0.9 \%(\mathrm{EC}=1.009)$ respectively for selected banks. Total productivity changes are increased of $A B$ Bank, BRAC Bank, Dhaka Bank, Dutch Bangla Bank, Pubali Bank and Janata Bank at the rate of $19.1 \%($ TFPC $=1.191), 7.5 \%(\mathrm{TFPC}=1.075), 1.7 \%$ $(\mathrm{TFPC}=1.017), 4.9 \% \quad(\mathrm{TFPC}=1.049), 0.7 \% \quad(\mathrm{TFPC}=1.007)$ and $4.6 \%$ (TFPC $=1.046)$ respectively. Productivity change is decreased for other selected banks. Total productivity, technical efficiency change and efficiency change are increased for $A B$ Bank, BRAC Bank and Janata
Bank at the rate of $19.1 \%($ TFPC $=1.191), 15.2 \%($ TEC $=1.152) 3.3 \%$ (EC=1.033). Eastern Bank, National Bank, One Bank, Prime Bank and Uttara Bank do not show effect on total productivity change, because all efficiency change is recorded equal to 1 .

\section{Conclusion}

This study employed a non-parametric approach, namely, the Cost DEA and Profit DEA to investigate efficiency of Bangladesh commercial banks and private banks and we investigated also the productivity change by employing Malmquist Productivity Index. By cost and profit DEA, the averages for technical, allocative and cost/ profit efficiency run between 0.75 and 0.24 with technical efficiency were at the higher end, while cost/profit were at the lower end. Both Mutual Trust Bank and One Bank are observed exact efficient for cost DEA and One Bank shows exact efficient in case of profit DEA. In terms of year wise analysis, both average of total productivity change and technical efficiency change by both cost and profit DEA were more than 0.9 , but with higher values were observed for both changes by profit DEA. During the year of 2001-2002, 2005-2006 and 2008-2009, total productivity change increased with decreasing rate consecutively based on cost DEA analysis.

Bank technical efficiency and total productivity change of $\mathrm{AB}$ Bank, Bank Asia, BRAC Bank and Dhaka Bank are increased and they are decreased for other selected banks but technical efficiency change increased for Pubali Bank and on the other hand total productivity 
Citation: Baten A, Kasim MM, Rahman M (2015) Efficiency and Productivity Change of Selected Online Banks in Bangladesh: A Non-parametric Malmquist Approach. J Internet Bank Commer 20: 121. doi:10.4172/2165-7866.1000121

Page 6 of 6

change is decreased for Pubali Bank. Meanwhile, the bank-wise average productivity change and technical efficiency change were also with values more than 0.9 but slightly less than the year wise averages but at a decreasing trend at rates of less than $5 \%$, whereas the efficiency change is increasing at a slow rate of less than $0.1 \%$ in case of profit DEA method.

\section{Recommendation}

Nowadays it has been appeared that banking sector, one of the most rising sector in Bangladesh, has been competing within the sector and each of the banks is trying to concentrate in making more profits. Investigating the results of this study the following recommendations are presented below:

In order to increase the profit efficiency each bank should use materials properly and be aware that whether it is wasted or not. Private Banks can expand their branch number to increase profit efficiency since they are not in the race to maximize profit and they need to stable cost. If this happens then there will be equilibrium. Since the Private Banks are interested to invest in Bangladesh, thus government should check it out why they are not increasing investment level and reform the investment policies for Private Banks. National Commercial Banks should be increased recruitments and proper utilize as like as Private Banks than NCBs profit maximize. Government should increase the size of the branch and give training the employees as well as recruit them at the new branches.

\section{Acknowledgments}

The authors wish to acknowledge the financial support provided by the $\mathrm{HIGH}$ IMPACT GROUP RESEARCH GRANT PENYELIDIKAN BERKUMPULAN IMPAK TINGGI (PBIT), (Grant number: 12870), Universiti Utara Malaysia, Sintok, Kedah, Malaysia, for conducting this research.

\section{References}

1. Casu B, Girardone C, Molyneux P (2004) Productivity Change in Banking:
A Comparison of Parametric and Non-Parametric Approaches. Journal of Banking and Finance 28: 2521-2540.

2. Seiford LM, Thrall RM (1990) Recent Developments in DEA: the Mathematical Programming Approach to Frontier Analysis. J Econometrics 4: 7-38.

3. Bauer PW (1990) Recent Developments in the Econometric Estimation of Frontiers. J of Econometrics 46: 39-56.

4. Green WH (1993) The econometric Approach to Efficiency Analysis in the measurement of Productive Efficiency.

5. Sohrab SM, Suzuki Y (2011) Financial Reform, ownership and Performance in Banking Industry: The Case of Bangladesh. International Journal of Business and Management 6: 28-39.

6. Hoque MR, Rayhan MI (2012) Data Envelopment Analysis of Banking Sector in Bangladesh. Russian Journal of Agricultural and Socio-Economic Sciences 5: 17-22.

7. Chowdhury TA, Ahmed K (2009) Performance Evaluation of Selected Private Commercial Banks in Bangladesh. International Journal of Business and Management 4: 86-97.

8. Hoque HA, Khan AR (2001) Financial Performance of Banks: A Statistical Analysis. Journal of Business Studies 22: 27- 49.

9. Bhattacharya A, Lovell CAK, Sahay P (1997) The Impact of Liberalization on the Productive Efficiency of Indian Commercial Banks. European Journal of Operations Research 98: 332-345.

10. Fukuyama H (1993) Technical and scale efficiency of Japanese commercial banks: A non-parametric frontier approach. Applied Economics 25: 1101-1112.

11. Favero CA, Papi L (1995) Technical Efficiency and Scale Efficiency in the Italian Banking Sector: A Non-parametric Approach. Applied Economics 27: 385-395.

12. Fare R, Grosskopf S, Lovell CAK (1985) The Measurement of Efficiency of Production. Kluwer-Nijhooff, Boston.

13. Fare R, Grosskopf S, Lindgern B, Roos P (1992) Productivity change in Swedish pharmacies 1980-1989: A non-parametric Malmquist approach. Journal of Productivity Analysis 3: 85-102.

14. Fare R, Grosskopf, Norris M, Zhang Z (1994) Productivity growth, technical progress and efficiency change in industrialized counties. American Economic Review 84: 66-83.
Citation: Baten A, Kasim MM, Rahman M (2015) Efficiency and Productivity Change of Selected Online Banks in Bangladesh: A Non-parametric Malmquist Approach. J Internet Bank Commer 20: 121. doi:10.4172/2165-7866.1000121

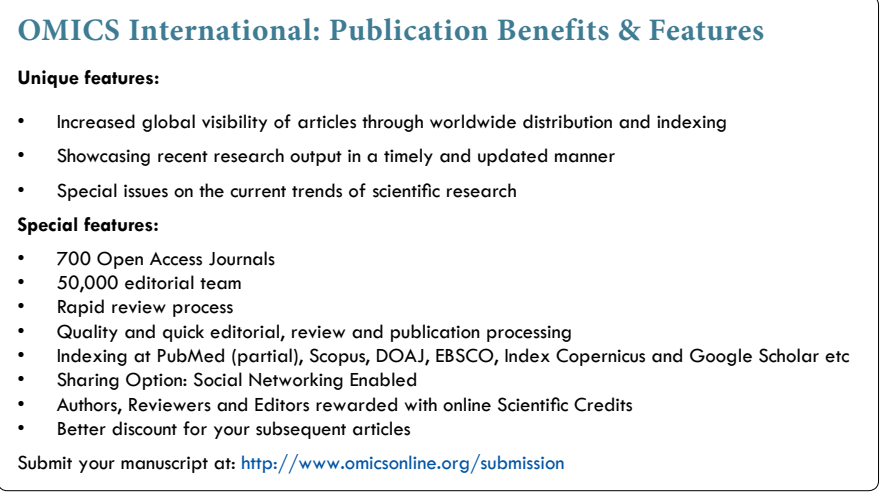

